\title{
HUBUNGAN PERSEPSI KLIEN TENTANG PENYAKIT GAGAL GINJAL KRONIK DENGAN PERUBAHAN HARGA DIRI DI RUANG HEMODIALISA RSUD DR. R. SOEDJATI SOEMODIARDJO PURWODADI
}

\author{
Oleh; \\ Anita Lufianti ${ }^{1)}$, Mustakhim ${ }^{2)}$ \\ 1). Staf Pengajar STIKES An Nur Purwodadi, email: kenzokensta@yahoo.com \\ 2) Mahasiswa STIKES An Nur Purwodadi, email: annurlppm@gmail.com
}

\begin{abstract}
ABSTRAK
Latar Belakang: Gagal ginjal kronis merupakan kerusakan ginjal progresif yang berakibat fatal dan ditandai dengan uremia. Penatalaksanaan pasien gagal ginjal kronik harus dilengkapi dengan technical treatment, antara lain tranplantasi ginjal, hemodialisis atau peritoneal dialysis. Pada tahun 2013 ada 1.185 kunjungan pasien gagal ginjal kronik di ruang hemodialisa. Penelitian ini bertujuan untuk mengetahui hubungan persepsi klien tentang penyakit gagal ginjal kronik dengan perubahan harga diri di ruang Hemodialisa RSUD Dr. R. Soedjati Soemodiardjo Purwodadi.

Metode: Penelitian korelasi dengan rancangan cross sectional pada 43 responden yang diambil secara accidental sampling. Pengumpulan data dengan kuisioner persepsi dan harga diri klien gagal ginjal kronik yang telah diuji validitas dan reliabilitas. Pengujian hipotesis penelitian dengan coeficient contingensi.

Hasil: Persepsi responden tentang gagal ginjal kronik di ruang Hemodialisa RSUD Dr. R. Soedjati Soemodiardjo Purwodadi Grobogan sebagian besar negatif sejumlah 26 responden $(60,5 \%)$ dan harga diri baik sejumlah 17 responden $(39,5 \%)$. Harga diri responden gagal ginjal kronik sebagian besar buruk sejumlah 26 responden $(60,5 \%)$ dan harga diri baik sejumlah 17 responden $(39,5 \%)$.

Simpulan: Ada hubungan antara persepsi klien tentang penyakit gagal ginjal kronik dengan perubahan harga diri di ruang Hemodialisa RSUD Dr. R. Soedjati Soemodiardjo Purwodadi Grobogan. Besarnya hubungan dalam kategori kuat karena koefisien kontingensi terletak antara 0,60-0,799 dengan arah korelasi positif.
\end{abstract}

Kata Kunci : Persepsi, Gagal Ginjal Kronik, Harga Diri 


\section{PENDAHULUAN}

Gagal ginjal kronis merupakan kerusakan ginjal progresif yang berakibat fatal dan ditandai dengan uremia (urea dan limbah nitrogen lainnya yang beredar dalam darah serta komplikasinya jika tidak dilakukan dialisis atau transplantasi ginjal) (Nursalam, 2008). Gagal ginjal kronik sering ditemukan, menurut data dari The United States Renal Data System (USRDS) tahun 2009 prevalensinya sekitar $10-13 \%$.

Di Amerika Serikat jumlahnya mencapai 25 juta orang, di Indonesia diperkirakan sekitar 18 juta orang. Prevalensi Gagal Ginjal Akut (GGA) di Indonesia sebesar 30/1.000.000 penduduk. Sebesar 5\% pasien rawat inap yang berada di rumah sakit di Indonesia mengalami GGA dan 2-5\% dari penderita yang dirawat di unit perawatan intensif (Suhardjono, 2009). Pada tahun 2010 di Indonesia terdapat sekitar 220.000 klien yang menjalani hemodialisis dan kemungkinan mortalitas akibat gangguan kardiovaskuler hampir 40\% (Lolyta, 2012).

Penatalaksanaan pasien gagal ginjal kronik tidak cukup dengan terapi tanpa obat misalnya diet, pembatasan cairan masuk, atau pengendalian faktor resiko dengan obat (Hipertensi, Infeksi saluran kencing dan diabetes mellitus), tapi harus dilengkapi dengan technical treatment, antara lain tranplantasi ginjal, hemodialisis atau peritoneal dialisis. Technical treatment yang paling ideal adalah tranplantasi ginjal, tetapi biasanya terkendala oleh masalah donor ginjal maupun biaya. Hemodialisis maupun peritoneal dialisis mempunyai kekurangan dan kelebihan. Kelebihan hemodialisis antara lain, cepat memperbaiki overhidrasi, hiperkalemia, asidosis metabolik, hipertensi persisten, tetapi dapat mengganggu hemodinamik, memperburuk aritmia, memperberat perdarahan (Purwanto, 2007).

Pada prinsipnya hemodialisa menempatkan darah berdampingan dengan cairan dialisat atau pencuci yang dipisahkan oleh suatu membran atau selaput semi permeabel. Membran ini dapat dilalui oleh air dan zat tertentu atau zat sampah. Proses ini disebut dialysis yaitu proses berpindahnya air atau zat, bahan melalui membran semi permeabel (Pardede, 2006).

Terapi hemodialisa adalah suatu teknologi tinggi sebagai terapi pengganti untuk mengeluarkan sisa-sisa metabolisme atau racun tertentu dari peredaran darah manusia seperti air, natrium, kalium, hidrogen, urea, kreatinin, asam urat, dan zat-zat lain melalui membran semi permeabel sebagai pemisah darah dan cairan dialisat pada ginjal buatan dimana 
terjadi proses difusi, osmosis dan ultra filtrasi (Setyawan, 2010).

Pasien dengan gagal ginjal sering kali merasa kehilangan kontrol akan dirinya. Mereka memerlukan waktu yang panjang untuk beradaptasi dan menyesuaikan diri dengan apa yang dialaminya. Perubahan peran adalah sesuatu yang tidak bisa dihindari. Sebagai contoh seorang pencari nafkah di keluarga harus berhenti bekerja karena sakitnya. Perasaan menjadi beban keluarga akan menjadi masalah buat individu ini. Selain itu juga pasien sering kali merasa dirinya "berubah". Adanya kateter yang menempel misalnya pada pasien dengan dialisis peritoneal, lesi di kulit, nafas berbau ureum dan perut yang membuncit membuat percaya diri dan citra diri pasien terpengaruh (Harvey dalam Andi, 2012).

Stimulus yang diterima individu akan mengalami persepsi. Persepsi merupakan suatu proses yang didahului oleh pengindraan, yaitu merupakan suatu proses yang berwujud yang diterimanya stimulus oleh individu melalui alat reseptornya. Proses itu tidak berhenti begitu saja melainkan stimulus itu diteruskan ke pusat susunan syaraf otak dan terjadilah suatu proses psikologis, sehingga individu menyadari apa yang ia lihat, apa yang ia dengar dan sebagainya. Dengan kata lain, individu tersebut mengalami persepsi. Karena proses penginderaan akan selalu terjadi setiap saat pada waktu individu menerima stimulus melalui alat inderaindera melalui reseptornya (Walgito, 2008).

Hasil penelitian terdahulu yang bertujuan untuk mengetahui hubungan antara persepsi terhadap penyakit dengan tingkat stres pada penderita diabetes mellitus tipe II di RSD Dr. Haryoto Lumajang, sampel berjumlah 100 penderita diabetes mellitus tipe II yang mengikuti rawat jalan di RSDDr. Haryoto Lumajang dan tidak sedang mengandung, dengan teknik pengambilan sampel secara insidental sampling, hasil penelitian menunjukkan dari analisis datamenggunakan korelasi product moment Pearson dengan nilai korelasi (r) 0,844 dan taraf signifikansi (p) 0,000 yang berarti terdapat hubungan linier positif antara persepsi terhadap penyakit dengan tingkat stres pada penderita diabetes mellitus tipe II di RSD Dr. HaryotoLumajang. Persepsi terhadap penyakit memberikan kontribusi sebesar $71,23 \%$ pada tingkat stres, sedangkan sisanya sebesar $28,77 \%$ dipengaruhi faktor lain (Wulandari, 2012).

Studi pendahuluan yang peneliti lakukan di RSUD Dr. Raden Soedjati Soemodiardjo Purwodadi-Grobogan tentang kunjungan pasien gagal ginjal kronik di ruang hemodialisa dari tahun 2010-2013 mengalami peningkatan yang 
sangat besar jumlahnya yaitu pada tahun 2010 ada 378 pasien, tahun 2011 ada 615 pasien dan tahun 2012 ada 754 pasien. Pada tahun 2013 ada 1.185 kunjungan pasien gagal ginjal kronik di ruang hemodialisa.

Hasil observasi awal yang dilakukan peneliti selama $3 \times 24$ jam pada pasien gagal ginjal kronik di ruang hemodialisa RSUD Dr. Raden Soedjati Soemodiardjo Purwodadi-Grobogan pada 10 klien, sebagian besar klien memiliki persepsi negatif terhadap perubahan citra diri sebesar $70 \%$ (7 orang) dan hanya ada $30 \%$ (3 orang) yang memiliki persepsi positif terhadap perubahan citra diri.

Berdasarkan studi pendahuluan tersebut peneliti merasa tertarik dan penting untuk melakukan penelitian tentang "Hubungan persepsi klien tentang penyakit gagal ginjal kronik dengan perubahan harga diri di ruang Hemodialisa RSUD Dr. R. Soedjati Soemodiardjo Purwodadi”.

\section{METODOLOGI}

Jenis penelitian yang digunakan adalah penelitian asosiatif yang mempunyai hubungan kausal, bertujuan untuk mengetahui hubungan antar dua variabel. Rancangan penelitian yang digunakan secara cross sectional
HASIL DAN PEMBAHASAN

Persepsi Responden tentang Gagal Ginjal Kronik

Tabel 1; Distribusi Persepsi Responden Tentang Gagal Ginjal Kronik

\begin{tabular}{|c|c|c|}
\hline Persepsi tentang GGK & $\mathbf{f}$ & $(\%)$ \\
\hline Positif & 17 & 39,5 \\
\hline Negatif & 26 & 60,5 \\
\hline Jumlah & 43 & 100 \\
\hline
\end{tabular}

Harga Diri Responden Gagal Ginjal Kronik

Tabel 2; Distribusi Harga Diri Responden Gagal Ginjal Kronik

\begin{tabular}{|c|c|c|}
\hline Harga Diri & $\mathbf{f}$ & $(\%)$ \\
\hline Baik & 20 & 46,5 \\
\hline Buruk & 23 & 53,5 \\
\hline Jumlah & 43 & 100 \\
\hline
\end{tabular}

Hubungan Persepsi Klien tentang Penyakit Gagal Ginjal Kronik dengan Perubahan Harga Diri

Analisa data yang bersifat bivariat untuk mengetahui hubungan variabel persepsi klien tentang penyakit gagal ginjal kronik dengan harga diri. Pemilihan uji hipotesis korelatif menurut Sopiyudin (2011) dengan variabel bebas berskala nominal dan variabel terikat berskala nominal uji korelasi yang digunakan adalah koefisien kontingensi. Hasil uji statistik disajikan pada table 3 di bawah ini: 
Tabel 3; Hubungan Persepsi Klien Tentang Penyakit Gagal Ginjal Kronik Dengan perubahan Harga Diri Di Ruang Hemodialisa RSUD Dr. R. Soedjati Soemodiardjo Grobogan

\begin{tabular}{|c|c|c|c|c|c|c|c|c|}
\hline \multirow{3}{*}{ Persepsi klien GGK } & \multicolumn{4}{|c|}{ Harga diri klien GGK } & \multirow{3}{*}{ Jumlah } & \multirow{3}{*}{$\%$} & \multirow{3}{*}{$\mathbf{p}$} & \multirow{3}{*}{$\mathrm{CC}$} \\
\hline & \multicolumn{2}{|c|}{ Baik } & \multicolumn{2}{|c|}{ Buruk } & & & & \\
\hline & $\mathbf{n}$ & $\%$ & $\mathbf{n}$ & $\%$ & & & & \\
\hline Positif & 16 & 94,1 & 1 & 5,9 & 17 & 100 & & \\
\hline Negatif & 4 & 15,4 & 22 & 84,6 & 26 & 100 & 0,000 & 0,611 \\
\hline Jumlah & 20 & 46,5 & 23 & 53 & 43 & 100 & & \\
\hline
\end{tabular}

Hasil uji hipotesis hubungan persepsi klien tentang penyakit gagal ginjal kronik dengan perubahan harga diri di ruang Hemodialisa RSUD Dr. R. Soedjati Soemodiardjo Purwodadi Grobogan dengan koefisien kontingensi diperoleh nilai $\mathrm{p}=0,000$ dan $\mathrm{CC}=0,611$, karena nilai $\mathrm{p}<0,05$ maka dapat diartikan bahwa ada hubungan antara persepsi klien tentang penyakit gagal ginjal kronik dengan perubahan harga diri di ruang Hemodialisa RSUD Dr. R. Soedjati Soemodiardjo Purwodadi Grobogan. Besarnya hubungan dalam kategori kuat karena koefisien kontingensi terletak antara 0,60-0,799 dengan arah korelasi positif.

\section{KESIMPULAN}

Ada hubungan persepsi klien tentang penyakit gagal ginjal kronik dengan perubahan harga diri di ruang Hemodialisa RSUD Dr. R. Soedjati Soemodiardjo Purwodadi Grobogan $\quad(p=0,000$ dan $\mathrm{CC}=0,611)$. Persepsi klien tentang penyakit Gagal Ginjal Kronik yang positif sejumlah 17 responden, dari responden tersebut terdapat 16 responden $(94,1 \%)$ yang memiliki harga diri baik dan 1 responden diantaranya $(5,9 \%)$ memiliki harga diri buruk. Persepsi klien tentang penyakit Gagal Ginjal Kronik yang negatif sejumlah 26 responden, dari responden tersebut terdapat 4 responden $(15,4 \%)$ yang memiliki harga diri baik dan 22 responden diantaranya $(84,6 \%)$ memiliki harga diri buruk.

\section{DAFTAR PUSTAKA}

Andi. (2012). Gangguan Psikiatrik Pada Pasien Ginjal. Jakarta: FKUI

Arikunto. (2010). Prosedur Penelitian Suatu Pendekatan Praktek. Jakarta: Rineka Cipta.

Arora, P., Varelli, M. (2010). Chronic Renal Failure. Available from: http://emedicine.medscape.com/article /238798-overview [Accessed 22 September 2013].

Budiarto. (2008). Biostatistik untuk kedokteran dan Kesehatan Masyarakat. Jakarta: EGC. 
Chayatin. (2009). Ilmu Kesehatan Masyarakat Teori dan Aplikasi. Jakarta: Salemba Medika.

Fitri Hastuti. (2012). Faktor-faktor yang Mempengaruhi Persepsi Pasien Tentang Konsep Diri pada Pasien Gagal Ginjal Kronik yang Menjalani Haemodialisa di Rumah Sakit Bhayangkara Tingkat I Raden Said Sukanto Jakarta Timur. Tesis: FIKUMJ.

Hidayat. (2007). Metode penelitian keperawatan dan teknik analisis data. Jakarta: Salemba Madika.

I Made Sukarja. (2008). Harga Diri dan Koping pada Pasien Gagal Ginjal Kronis di RSUP Sanglah Denpasar. From: Jurnal Skala Husada Volume 5 Nomor 2, 2008: 132-136.

Indonesian Nursing. (2008). Hubungan Citra Tubuh Dengan Kualitas Hidup Pasien Gagal Ginjal Kronik Yang Menjalani Hemodialisis. From: http://repository.usu.ac.id/bitstream/1 23456789/27526/7/Cover.pdf

Keliat, B. A. (2009). Proses Keperawatan Jiwa. Jakarta: ECG.

Kozier. (2004). Fundamental of Nursing : Concept, Process, and Practice. Jakarta: EGC.

Lolyta. (2012). Analisis Faktor Yang Mempengaruhi Tekanan Darah Hemodialisis Pada Klien Gagal Ginjal Kronik (Studi Kasus Di Rs Telogorejo Semarang) From: http://www.ejurnal.com/2013/10/analisis-faktoryang-mempengaruhi.html

Mansjoer. (2005). Kapita Selekta Kedokteran. Edisi III. Jakarta: Media Aesculapius.
Notoatmodjo. (2010). Metode Penelitian Kesehatan. Jakarta: Rineka Cipta.

Nursalam. (2008). Asuhan Keperawatan pada Pasien dengan Gangguan Sistem Perkemihan. Jakarta: Salemba Medika.

Nursalam. (2008). Metodologi Riset Keperawatan. Jakarta: Salemba Medika.

Pardede. (2006). Hemodialisa. Diunduh dari : http://annurhospital.com. Diakses tanggal 4 September 2013.

Perhimpunan Nefrologi Indonesia (PERNEFRI). (2008). Penyakit Ginjal Kronik dan Glomerulopati: Aspek Klinik dan Patologi Ginjal. Jakarta: PERNEFRI.

Potter dan Perry. (2005). Buku ajar fundamental keperawatan, konsep, proses dan praktik. Jakarta: EGC.

Pranay, K., Stoppler, M.C. (ed). (2010). Chronic Kidney Disease. Available from:http://www.emedicinehealth.co m/chronic_kidney_disease/page18_e m.htm\#Authors\%20and\%20Editors [Accessed 19 September 2013]

Price, S.A. \& Wilson, L.M. (2006). Patofisiologi, edisi 6. Jakarta: EGC.

Prodjosudjadi, W \& A. Suhardjono. (2009). End-Stage Renal Disease In Indonesia: Treatment Development. Ethnicity \& Disease. Volume 19. From: http://www.ishib.org/journal/191s1/ethn-19-01s1-33.pdf. Diakses 10 September 2013.

Purwanto. (2007). Pengantar Perilaku Manusia Untuk Keperawatan. Jakarta: EGC. 
Riwidikdo. (2010). Statistik Kesehatan. Jogjakarta : Mitra Cendikia Press.

Robbins. (2008). Prinsip-prinsip Ilmu Perilaku. Jakarta: Erlangga.

Sastroasmoro. (2010). Dasar-Dasar Metodologi Penelitian Klinik. Jakarta : EGC.

Setyawan. (2010). Gagal Ginjal. Jakarta: PT. Gramedia.

Smeltzer. (2006). Buku Keperawatan Medikal. Jakarta: EGC.

Sopiyudin. (2011). Statistik Untuk Kedokteran dan Kesehatan, edisi 5. Jakarta: Salemba Medika.

Sugiyono. (2008). Statistik Untuk Penelitian. Bandung: CV. Alfabeta.

Suhardjono, dkk., 2001. Gagal Ginjal Kronik. Buku Ajar Ilmu Penyakit Dalam. Jakarta: FKUI.

Sunaryo. (2004). Psikologi untuk Keperawatan. Jakarta: EGC.

Suyono. (2010). Ilmu Penyakit Dalam. Jakarta : FKUI.

Syarifudin. (2010). Panduan TA Keperawatan dan Kebidanan dengan SPSS. Yogyakarta: Grafindo Litera Media.
Supriyadi. (2011). Tingkat Kualitas Hidup Pasien Gagal Ginjal Kronik Terapi Hemodialisis. From: http://journal.unnes.ac.id/index.php/ke mas

Wald \& Alvaro. (2008). The Risk of Gallbladder Stone Formation Is Increased in Patients with Predialysis Chronic Kidney Disease but Not" ose Undergoing Chronic Hemodialysis Therapy. Nephron Clin Pract, 111: c167-c172

Walgito. (2008). Psikologi Sosial Suatu Pengantar. Yogyakarta: Andi.

Widi. (2009). Hubungan Antara Riwayat Gagal Ginjal Kronik dengan Mortalitas Gagal Jantung Akut di Rumah Sakit. From: lontar.ui.ac.id/file?file=digital/126917 -S09136fk

Winardi. (2003). Pengantar tentang Teori Sistem dan Analisis Sistem. Jakarta: PT.Raja Grafindo Persada.

Yuliaw. (2009). Karakteristik Pasien Dan Kualitas Hidup Pasien Gagal Ginjal Kronik Yang Menjalani Terapi Hemodialisa. From: jurnal.usu.ac.id/index.php/jkk/article/. ../1058/160 Diakses 21 April 2014.

Zuyina. (2010). Pendekatan Kualitatif dalam Penelitian Psikologi. Jakarta: LPSP3 Universitas Indonesia 